\title{
Attitude Towards Menstruation Among Female In-School Adolescents: A Comparative Cross-Sectional Study in Southwest Nigeria
}

\author{
Olufemi Oludare Aluko ( $\square$ ooaluko@gmail.com ) \\ Obafemi Awolowo University https://orcid.org/0000-0002-5726-5806 \\ Jireh Ngozi Udechukwu \\ Olabisi Onabanjo University Obafemi Awolowo College of Health Sciences \\ Oluwaseun Anthonia Loto \\ Obafemi Awolowo University \\ Ayoola Oluwaniyi Orisawayi \\ Obafemi Awolowo University Teaching Hospital Complex \\ Grace Ojodomo Ojogba \\ Obafemi Awolowo University \\ Promise Oluwaseun Arowosafe \\ Obafemi Awolowo University College of health Sciences
}

Research article

Keywords: menarche, menstrual attitude, openness, feelings, menstrual symptoms, Nigeria

Posted Date: August 6th, 2020

DOI: https://doi.org/10.21203/rs.3.rs-42447/v1

License: (1) This work is licensed under a Creative Commons Attribution 4.0 International License. Read Full License 


\section{Abstract}

Background: Menarche and menstruation are natural procedures in a girl's transition to womanhood. Lack of awareness thereof, before menarche and stigmatizing menstrual hygiene management (MHM) perception and experiences predominate in low resource economies and influences attitude. The study aims to determine and compare the attitude of adolescents attending public and private schools on menstruation and MHM in the study area.

Methods: The cross-sectional study recruited 357 respondents, comprising of 177 and 180 female adolescents from public and private schools through a three-stage sampling technique. The study administered a validated, semi-structured questionnaire that was facilitated self-administered. Descriptive and inferential statistics presented results, while binary logistic regression identified predictors of attitude at $\mathrm{P}_{\dot{\mathrm{a}}} 0.05$.

Results: Except for religion, other socio-demographic characteristics (age, class, ethnicity, whom adolescents' lives with, highest education and wealth) were significantly different between public and private schools. However, respondents in public schools were older (15.4 \pm 1.75 years) when compared with those attending private schools ( $14.3 \pm 1.18$ years). On attitude, negative feelings and openness scales were significantly different between respondents attending public and private schools, while those of positive feelings, menstrual symptoms, acceptance of menarche and living with menstruation were respectively similar at $P_{a} 0.05$. Overall attitude scale indicated a higher negative rating (87.4) when compared with a positive score (12.6\%). With a positive attitude as a reference, ethnicity was the only negative attitude predictor $\left(\mathrm{P}_{\mathrm{a}} 0.05\right)$.

Conclusions: Adolescents attending public and private schools have negative attitudes toward menstruation and MHM. Therefore, awareness and puberty education through ethnic constructs, on menstruation and MHM before menarche is indispensable to improve their attitude.

\section{Plain English Summary}

Menstruation is natural and experienced by females starting with menarche, and until menopause. Before menarche, adolescent females should be aware and knowledgeable about menstruation and the appropriate menstrual hygiene management practices, to inform their attitude to menstruation. In this study, the researchers sought the opinions of adolescent females attending public and private schools as to their opinions on the six menstrual attitude scales to determine the situation in the study area.

The adolescent menstrual attitude scale of 58 items, apart from socio-demographic questions was validated and used in the survey.

Of the 357 respondents, 177 and 180 were respectively from public and private schools. The Ministry of Education and Institute of Public Health of the Obafemi Awolowo University gave institutional approval, while parents and respondents gave consent and assent, respectively before the study.

The study showed that most respondents, irrespective of the type of school attending had overall and individual negative scores in all adolescent menstrual attitude domains assessed, except living with menstruation sub-scale. Ethnicity was also identified as a factor to consider in promoting positive menstrual attitude among adolescent female learners.

In conclusion; basic-level education stakeholders should consider structured puberty education to enhance menstruation and related knowledge, awareness and counselling in foundational classes before menarche. This may enhance their attitude towards menstruation before menarche.

\section{Background}

Adolescents are aged between 10 and 19 years (1) and constitute one-sixth of the worlds' population (2). Adolescence signals the transition from childhood, to adulthood, and associated with rapid pubertal development and sexual maturation (3). During pubertal development, psychological, cognitive, hormonal and physical changes occur with diverse variations in individuals, because of environmental, nutritional and genetic factors $(4,5)$. Adolescence heralds menarche (6), a rite of passage for girls, that signals the transition to womanhood (5). The menstrual cycle has three phases; the follicular, ovulation and luteal (secretory) phases, regulated by hormones $(3,7)$. Menstruation sheds two-thirds of the endometrial lining. The intensity and duration of menstrual flow vary (between 3-5 days and occasionally up to seven days) in individuals and at different life phases $(1,8,9)$. The resultant waste during menstruation is termed menses, periods, or monthly bleeding (10) that need to be considered and managed with dignity. 
Knowledge and awareness shapes attitude, which influences behaviour (11) and a diverse lacuna in the knowledge about menstruation among adolescent girls prevail $(3,5)$. The attitude towards menstruation and menstrual hygiene management (MHM) is crucial in adolescence and modified by socio-demographic and economic factors, such as parental, societal, and cultural, tribal, and school-related influences. In some climes, a menstruating female is ostracised, excluded from associating with others and barred from societal and religious functions (12-15), a condition that exerts a psycho-social apprehension in the female adolescent who has just started menstruation.

The absence of age-appropriate scale to measure adolescents attitude to menstruation before- and after-menarche was bridged and validated in 1993 by Morse, Kieren and Bottorff (16). The scale has six domains, adapted and applied in this study. Several studies listed attitude in titles which when assessed delved on knowledge and some practice variables while attitude was sparsely reported and discussed.

Objectives: Considering the importance of attitude to menstruation and MHM, we explored adolescent attitude through the adolescent menstrual attitude questionnaire (MAQ), (16) to identify adolescents attitudes and its predictors during the menstruation formative years among female, in-school adolescents.

\section{Methods}

\section{Description of the study area}

As shown in Figure 1, the study was conducted in Ife East local government area (LGA). The LGA is a heterogeneous urban LGA, and one of the ten LGAs in Osun-East senatorial district in Nigeria. It occupies $172 \mathrm{~km}^{2}$ within latitudes $7^{\circ} 28^{\prime} \mathrm{N}$ and $7^{\circ} 45^{\prime} \mathrm{N}$ and longitudes $4^{\circ} 30^{\prime} \mathrm{E}$ and $4^{\circ} 34^{\prime}$ E. Its 2006 population was 188,614 out of which $24.1 \%$ were adolescents (17). The LGA has 51 secondary schools, stratified into public (19), and private (32) types.

\section{Study Design}

The study was comparative and cross-sectional in nature among female adolescents attending randomly selected public and private schools in the study area.

\section{Target Population}

The study targeted post-menarche adolescents in public and private schools.

\section{Sample Size}

The minimum sample was calculated from the formula for comparing proportions in similar populations with $Z_{a}$ at $95 \%$ confidence level $=1.96, Z_{\beta}$ (probability of making type 2 error) at $1-\beta$ power of $95 \%=1.64, p^{0}=64.25 \%$ and $p^{1}=35.75 \%$. 80 was the minimum sample size, adjusted for non-response (10\%) and, with design effect (2) to 178 respondents, per group.

\section{Sampling technique}

The multi-stage sampling technique identified respondents as follows. Stage one stratified the 51 schools into public (19) and private (32) schools while stage-two listed the schools in each category identified two from each category through random sampling without replacement technique. In stage three, the female students who have attained menarche were given numbers and respondents identified through proportional to size method, across all classes of study in the schools.

\section{Inclusion and Exclusion Criteria}

The study studied in-school, female adolescents in randomly selected public and private schools that have achieved menarche, had parental consents and gave personal assent. In contrast, those eligible respondents that were either sick or with parental consent and personal assent withheld were excluded.

\section{Pre-test and validation of data collection instruments}

The data collection instruments were adapted from the validated menstrual adolescent questionnaire (16), and literature (18-20). The instrument was pretested on 20 female adolescent students that have achieved menarche in a secondary school at Ife Central LGA. The 
pre-test observations and findings were used to correct ambiguity and improve the instrument's local contents, before use for field data collection. The pre-tested instrument was facilitated, self-administered on adolescents between January and March 2019.

\section{Data Analysis}

Epi-data manager software version 4.4.2.1 was used for data entry before exporting to International Business Machine (IBM)-Statistical Package for Social Sciences (SPSS) version 20 for data cleaning and analysis. Descriptive statistics were used to present summary data through means (standard deviation) for continuous variables; frequency (\%) and charts for categorical variables. The differences between private and public schools were explored with chi-square statistics while predictors of the attitude of female adolescents towards menstruation and related perceptions were explored through binary logistic regression analysis. The Cronbach's alpha reliability coefficient was $66.3 \%$ for the adapted scale applied for field data collection. Variables reporting were based on completed entries without considerations for missing data in the dataset.

\section{Measurement of dependent and independent outcomes}

Attitude: The attitude of respondents was measured through the adapted post-menarche version of the Adolescent MAQ scale. The 58 items were in six blocks: positive feelings ( 11 items), negative feelings ( 18 items), menstrual symptoms ( 9 items), openness (5 items), acceptance of menarche ( 7 items) and living with menstruation (8 items). For each of the derived composite indices, the summation of the mean scores of each variable was computed. The range of measurements (4) was divided by the maximum obtainable score (5), to derive the measurement interval of 0.8 , which was added to the minimum obtainable score to derive the upper limit of each category. To dichotomous the derived variable, strongly agree and agree scores (3.41-5) was rated as positive attitude, while undecided, disagree and strongly disagree scores (1-3.4) was rated as negative attitude (21).

Also, the derived wealth index computed from 15 household items. The predominant factor category in the factor reduction, Principal Component Analysis (PCA) was used to categorize respondents into poor, average and rich groups (22-24).

\section{Results}

The mean age of female adolescents studied was $14.8 \pm 1.58$, with 11 and 19 as the minimum and maximum ages, respectively. Respondents in public schools were older ( $15.4 \pm 1.75$ years) when compared with those in private schools $(14.3 \pm 1.18$ years). Besides, about two-thirds of respondents $(66.7 \%)$ belonged to middle adolescence, though higher proportions $(75.0 \%)$ were in private school when compared with the public school (58.9\%). More respondents in private school were in senior secondary classes in contrast to those in the public school where $51.4 \%$ were in senior secondary classes. Yoruba ethnicity and Christianity predominate across the two study groups. Also, most adolescents reside with both parents with a higher proportion (87.8\%) in the private school setting. Among the primary caregiver of respondents, modal education was secondary and tertiary education respectively among those attending public and private schools while most guardians were poor (46.3\%) and average (43.3\%) among caregivers of female adolescents attending public and private schools, respectively (Table 1).

\section{Menstrual attitudes dimensions among in-school adolescents}

The female adolescents' menstrual attitude assessment measured in six domains is presented in Table 2. On positive feelings, only $33.3 \%$ of respondents exhibited a positive rating on positive feelings domains while $66.7 \%$ had a negative rating on positive feelings composite block. The distribution of positive feelings among female adolescents in public and private secondary schools respectively with $36.2 \%$ and $30.6 \%$ respectively in positive rating. The difference between public and private schools' distributions on positive feelings was not statistically significant $(\mathrm{p}=0.262)$, indicating that the distribution was not associated with the type of schools attending. Most respondents had a negative attitudinal rating on negative menstruating and menstrual hygiene feelings with $79.7 \%$ and $87.8 \%$ score respectively, presenting also a weak positive difference between adolescents attending public and private schools $(p=0.038)$. The composite menstrual symptoms attitude scores showed similarity and no significant difference $(p=0.112)$ female adolescents attending public and private schools. Most respondents showed negative feelings towards menstrual symptoms experiences. However, the odds of experiencing negative menstrual symptoms by adolescents attending public schools was 1.5 higher than those in private schools (Table 2).

The attitude of adolescent females in discussing issues about menstruation and menstrual hygiene management concerns was negatively skewed $(92.7 \%$ and $82.8 \%$ in public and private schools, respectively) and significantly different $(\mathrm{p}=0.05)$ between public and private schools. Also, the odds of openness by adolescents attending public schools was 2.6 higher than those in private schools. 
Adolescents in private schools had better attitude scores in the 'acceptance of menarche' and 'living with menstruation' domains as opposed to their counterparts in public schools. There was no significant difference $(p=0.139)$ between adolescents attending public and private schools on acceptance of menarche though the odds of adolescents attending public schools was 1.4 higher than those in private schools on the acceptance of menarche when experienced. Similarly, there was a strongly significant difference $(p=0.0001)$ on the attitude of respondents regarding living with menstruation while the odds of adolescents attending private schools living with menstruation was 2.8 higher than those in public schools (Table 2)

The consideration of the 58 attitudes rating scale as a composite variable showed a skewed negative rating (87.4\%) when compared with positive attitude score (12.6\%). Also, there was a significant difference in the association $(p=0.020)$ between adolescents attending public and private schools while the odds of menstruation and menstrual hygiene attitude was 2.2 when public school was compared with the private school, respectively (Figure 2)

\section{The relationship between menstrual attitudes and selected socio-demographic variables}

The result of the multivariate analysis predicting attitude of adolescents attending public and private schools was done through multivariate regression with a positive attitude as the reference category of the dependent variable (Table 3). The analysis identified ethnicity as the only predictor $(P<0.05)$ responsible for the attitude of adolescents attending schools in the study area. The respondents' age, class, religion, who living with, Caregiver's highest level of education and wealth categories had no significant influence on the attitude of adolescents on menstruation and menstrual hygiene management.

\section{Discussion}

The adolescence ages in females signal the transition from girlhood to womanhood, marked with the onset of menarche and puberty (4). Before menarche, a girl child is expected to be informed (25) about psychological, cognitive, hormonal, physical body changes (3) and individual modifying factors that contributed to preformed attitude on menstruation and menstrual hygiene behaviour (26); and subsequently adolescents reproductive health transition to adulthood, especially for in-school adolescents. We evaluated the attitude of adolescents from six domains, towards an overall attitude formation by female adolescents on drivers of menstruation in a developing economy, among public school and private school attending adolescents.

\section{Sociodemographic characteristics of respondents}

The age of female adolescents studied corresponds to those reported among adolescence in similar studies in Nigeria and elsewhere $(5,27-34)$ since the age range of adolescent is between 10 and 19 years. While the mean age of adolescents' studies in public schools remains at between 15-17 years, indicating demographic stagnation among females attending public schools in contrast to reducing ages (14.3 \pm 1.18 years) of adolescents attending private schools. Also, adolescents attending private schools have higher socioeconomic status when compared with those attending public schools $(25,35-37)$, which is also expected since parents/guardians pay tuition and other associated fees in private schools, in contrast to largely free education in public schools.

\section{The attitude of in-school adolescent girls to menstruation}

The outcome of the six attitude indicators revealed no difference between female adolescents attending public and private schools. The positive feelings regarding the perception of menstruation as a natural physiological event were captured in positive feelings domain and as a matter of fact, female adolescents are expected to be prepared for menarche before experiencing it. However, most respondents in public (36.2\%) and private (30.6\%) schools perception was negative on positive feelings domain and therefore are ill-prepared to experience it, in congruence with a study by Marvan and Molina-Abolnik in Mexico (38) and in Ghana, which however changed after strategic intervention where more girls became aware of when to expect their menses monthly with $92 \%$ of girls reported positive feelings about menstruation (39).

Similarly, negative emotions, which entails embarrassment, rejection and wishing they could stop menstruation showed that most respondents had a weak attitude. In our study, negative feelings, through a feeling of shame, embarrassment and hope menstruation could stop, rather than being happy about their transition to womanhood was predominant in private schools (12.2\%) when compared to public schools (20.3\%), respectively, in congruence to findings of Marvan and Molina-Abolnik in Mexico $(38)$ and Nigeria $(30,32,33)$ and elsewhere $(5,40,41)$. 
The derived menstrual symptoms variable showed that only $22.6 \%$ and $30.0 \%$ among respondents in public and private school respectively had a positive attitude while others showed a negative attitude, as in previous studies (42-44). The signs and symptoms that herald menarche, and subsequent menstruations on monthly basis vary from one adolescent to another, as also in the postmenarche female adolescents where a significant negative correlation between menstrual attitudes and perimenstrual symptoms in Uganda (45), a product of inadequate and skewed awareness, and preparedness to manage some menstruation and associated discomforts $(19,32,42)$.

The ease with which adolescents communicate about menstruation, including but not limited to feelings about the purchase and handling menstruation materials, information seeking pattern, as part of openness, was largely negative, in congruence with findings in Uganda, and other climes where a silent culture of secrecy, inadequacy, shame and insecurity pines menstruation and menstrual hygiene management (38,45-48). Also, on their acceptance of menarche, adolescents attending public and private schools had $28.2 \%$ and $35.6 \%$ positive rating scores respectively, a pointer to the inherent challenges experienced. The study findings were in agreements with similar studies that considered menarche experience as debilitating, bothersome and scary (30,42,49-51); associated with negative emotions (5), perhaps due to inadequate menarche education and preparedness for menstruation (48). This has persisted despite several decades of awareness creation and interventions to improve the situation among adolescents globally $(11,19,52-55)$

It was, however, only living with menstruation that had $51.3 \%$ overall positive attitude scores in agreement with a previous study in Egypt (56). They have accepted menstruation and its management as a routine that should happen monthly despite being negatively affected by friction burns on their thighs during journeys to school (57) and experiences of cramps, fatigue and feeling discomfort, backache and types of absorbents used could affect their attitude and contribute to school absenteeism and performance $(42,58,59)$.

The positive scores in a composite of the 58 attitude items of adolescents in public (8.5\%), private (16.7\%) and overall (12.6\%) were poor and lower than those reported by Yadav et al. (60) and Padmanabhanunni and Fennie (61), where $49 \%$ and $78 \%$ of adolescents and university students respectively had positive attitudes towards menstruation and menstrual hygiene management. Lawal, Idemudia and Balogun reported that adolescent girls with lower anxiety reported positive menstrual attitude by anticipating the onset of menstruation (30) and therefore, the poor attitude could have been occasioned by low, to skewed awareness prior menarche and information received from divergent sources due to the culture of silence that herald menarche. These agreed with previous findings where most respondents had a negative attitude attributed to negative beliefs about menstruation in beliefs, and culture $(38,62,63)$. However, adolescents may consider menstruation and its management more positively if they are surrounded and equipped with the right knowledge, encouraging societal perceptions, removal of negative socio-cultural beliefs and practices, aspects of menstruation $(48,62)$.

Though previous studies identify religious affiliation and income level as factors that predict attitude to menstrual attitudes and experiences (7) in contrast to the current study where adolescent girls' attitude to menstruation was a function of ethnicity. Adolescents attending private schools have a better attitude when compared to those in public schools and therefore, the inherent factors need to be further researched. The study findings apply to female in-school adolescents attending public and private schools in developing economies.

\section{Study Limitations}

The study was prone to response bias among adolescents attending public and private schools in Nigeria and reported a low Cronbach's alpha reliability coefficient (66.3\%). The responses were self-facilitated after the questions were explained to participants spaced out to avoid undue influence on their responses.

\section{Conclusions}

There were similarities in the attitude of adolescents attending public and private schools. Their attitude was generally negative on the six attitude domains assessed and therefore, drivers such as ethnicity, awareness, providing adequate and timely knowledge before menarche and provision of right menstrual hygiene management environment and materials should be linked to enhance the perception and practice of in-schools adolescents positively in the study area.

\section{Abbreviations}

IBM International Business Machine

LGA Local Government Area 
MHM Menstrual Hygiene Management

PCA Principal Component Analysis

SPSS Statistical Package for Social Sciences

\section{Declarations}

\section{Ethics approval and consent to participate}

Permission for the study was obtained from the Ministry of Education in the State, through the Ife East Local Education Office. The Parents-Teachers Associations executives of the four schools gave verbal permission for the schools to be used for the study after understanding the purpose and objectives of the research. Also, parents of participants approved the participation of their wards in the study, through signed consent forms. Thereafter, verbal assent of the respondents was sufficient since the study did not involve any invasive procedures (64). The research and ethics committee of the Institute of Public Health of the Obafemi Awolowo University in Nigeria approved the study protocol (IPH/OAU/12/1242) before to field data collection.

\section{Consent for publication}

Not applicable

\section{Availability of data and materials}

The datasets used and/or analysed during the current study are available from the corresponding author on reasonable request

\section{Competing interests}

The authors declare that they have no competing interests

\section{Funding}

This research did not receive any specific grant from funding agencies in the public, commercial, or not-for-profit sectors.

\section{Authors' contributions}

JNU and OOA conceived while all authors contributed to the study design, JNU, OAL, GOO, POA and OO supervised field data collection, entry, analyses, and interpretation of the summary tables. OAA and JNU wrote the introduction and methods. GOO and OAL and OO wrote the first draft of results while $\mathrm{OO}$ coordinated the integration of feedback into the manuscript. All authors contributed to the discussion and abstract write-up and vetted and approved the final draft.

\section{Acknowledgements}

The authors acknowledged the immeasurable support of the State Ministry of Education, the headteachers and Parent Teachers Associations in the four selected schools, the parents of the selected female adolescents and the menstruating adolescents' females for their support and cooperation during the field data collection. We appreciate the time and patience of the respondents whose efforts led to data presented in this manuscript, we appreciated the time and expertise of the manuscript handling editor and the peer reviewers for improving the quality and presentation of the manuscript.

\section{References}

1. Wall L., Teklay K, Desta A, Belay S. Tending the 'monthly flower:' a qualitative study of menstrual beliefs in Tigray, Ethiopia. BMC Women's Health. 2018;18(1):183.

2. WHO. Young people: health risks and solutions [Internet]. WHO Media Centre. 2011 [cited 2019 Apr 18]. Available from: https://www.who.int/news-room/fact-sheets/detail/adolescents-health-risks-and-solutions 
3. Kaur R, Kaur K, Kaur R. Menstrual Hygiene, Management, and Waste Disposal: Practices and Challenges Faced by Girls/Women of Developing Countries. J Environ Public Health [Internet]. 2018 Feb 20 [cited 2019 Apr 18];2018:1-9. Available from: https://www.hindawi.com/journals/jeph/2018/1730964/

4. Fatunmbi OJ, Usman SO, Adesina A, Sunday O, Usman IN, Odesanmi AT, et al. Menstrual Training and Hygiene Management Among Adolescents in South-Western Nigeria: A Cross-Sectional Study. 2017;2(1):106-13.

5. Coast E, Lattof SR, Strong J. Puberty and menstruation knowledge among young adolescents in low-and middle-income countries: a scoping review [Internet]. Vol. 64, International Journal of Public Health. Springer International Publishing; 2019 [cited 2019 Apr 18]. p. 293-304. Available from: http://link.springer.com/10.1007/s00038-019-01209-0

6. Edmonds DK. Dewhurst's Textbook of Obstetrics \& Gynaecology. Dewhurst's Textbook of Obstetrics \& Gynaecology: Eighth Edition. 2012. 26-32 p.

7. Johnston-Robledo I, Stubbs ML. Positioning Periods: Menstruation in Social Context: An Introduction to a Special Issue. Sex Roles [Internet]. 2013 Jan 3 [cited 2019 Apr 18];68(1-2):1-8. Available from: http://link.springer.com/10.1007/s11199-012-0206-7

8. House S, Mahon T, Cavill S. Menstrual Hygiene Matters: A resource for improving menstrual hygiene around the world. Reprod Health Matters [Internet]. 2012;21(41):257-9. Available from: http://linkinghub.elsevier.com/retrieve/pii/S0968808013417123

9. Aburshaid F, Ahmad S, Ashmauey A, Mohammad H. Effect of Planned Health Educational Program on Menstrual Knowledge and Practices among Adolescent Saudi Girls. J Nurs Heal Stud. 2017;02.

10. Swenson I, Havens B. Menarche and Menstruation: A review of the Literature. J Community Health Nurs [Internet]. 1987 Dec;4(4):199-210. Available from: http://www.tandfonline.com/doi/abs/10.1207/s15327655jchn0404_3

11. Bhavna L, Remia M, Gupta RK, Rashmi K, Rayaz J, Richa M. Impact of menstrual awareness and knowledge among adolescents in a rural area. Indian J Community Heal [Internet]. 2015;27(4):456-61. Available from: http://ovidsp.ovid.com/ovidweb.cgi? $T=J S \& C S C=Y \& N E W S=N \& P A G E=$ fulltext $\& D=$ cagh\&AN $=20163215498$

12. Guterman M.A., Mehta P. GMS. Menstrual Taboos Among Major Religions. Internet J World Heal Soc Polit. 2012;5(2).

13. Onyilo G, Ominyi J, Ogunjobi B, Agberemi B. Menstrual Hygiene Management in Schools and Communities in Nigeria. WHO 2018. 2008;

14. Gharoro LA. Menstrual Hygiene Practices among Junior Secondary School Students in Benin City. J Educ Soc Res [Internet]. 2013 Oct 1;3(8):129-36. Available from: http://www.mcser.org/journal/index.php/jesr/article/view/1748

15. Onyegegbu N. Improvement of Menstrual Hygiene Management among Girls in Schools and Communities in Nigeria: A Case for Active Contributions of Various Stakeholders. In: 4th Annual Virtual Menstrual Hygiene Management in Schools Conference. 2015.

16. Morse JM, Kieren D, Bottorff J. The adolescent menstrual attitude questionnaire, part I: Scale construction. Health Care Women Int [Internet]. 1993 Jan [cited 2019 Apr 18];14(1):39-62. Available from: http://www.tandfonline.com/doi/abs/10.1080/07399339309516025

17. National Population Commission. The Federal Republic of Nigeria, 2006 Population and Housing Census. Population distribution by age and sex, priority table volume IV. [Internet]. National Population Commission. Abuja, Nigeria: NPC; 2010. p. 1. Available from: www.population.gov.ng/images/priority table

18. Phillips-Howard PA, Caruso B, Torondel B, Zulaika G, Sahin M, Sommer M. Menstrual hygiene management among adolescent schoolgirls in low- and middle-income countries: Research priorities. Glob Health Action [Internet]. 2016 Dec 8 [cited 2019 Apr 18];9(1):33032. Available from: https://www.tandfonline.com/doi/full/10.3402/gha.v9.33032

19. Kuhlmann AS, Henry K, Wall LL, K. and Wall LLKASH. Menstrual Hygiene Management in Resource-Poor Countries. Vol. 72 , Obstetrical and Gynecological Survey. 2017. p. 356-76.

20. Katsuno C, Gregorio ER, Lomboy MFTC, Nonaka D, Hernandez PMR, Estrada CAM, et al. Quality of public school toilets and the frequency of changing sanitary napkins among students in public secondary schools in the City of Manila, Philippines. Trop Med Health [Internet]. 2019 Dec 11 [cited 2019 Aug 20];47(1):1-10. Available from: https://tropmedhealth.biomedcentral.com/articles/10.1186/s41182-018-0131-8

21. Krosnick, Jon A and Presser S. Question and Questionnaire Design. In: Marsden, Peter V. and Wright JD, editor. Handbook of Survey Research. Second Edi. Emerald Group Publishing Limited; 2010. p. 263-314.

22. Roche R, Bain R, Cumming O. A long way to go - Estimates of combined water, sanitation and hygiene coverage for 25 sub-Saharan African countries. Zeeb H, editor. PLoS One [Internet]. 2017 Feb 9 [cited 2017 Jun 13];12(2):e0171783. Available from: http://dx.plos.org/10.1371/journal.pone.0171783 
23. Aluko 000, Oloruntoba EOO, Chukwunenye UAA, Henry EUU, Ojogun E. The dynamics and determinants of household shared sanitation cleanliness in a heterogeneous urban settlement in Southwest Nigeria. Public Health [Internet]. 2018 Dec 1 [cited 2018 Nov 1];165:125-35. Available from: https://www.publichealthjrnl.com/article/S0033-3506(18)30302-

0/fulltext\#.W9rkACIK_mA.mendeley

24. Abramovsky L, Augsburg B, Oteiza F. Baseline report: Sustainable Total Sanitation - Nigeria [Internet]. 7 Ridgmount Street London, London WC1E 7AE: The Institute for Fiscal Studies; 2019 [cited 2019 Aug 23]. 1-149 p. Available from: http://www.ifs.org.uk

25. Chandra-Mouli V, Patel SV. Mapping the knowledge and understanding of menarche, menstrual hygiene and menstrual health among adolescent girls in low- and middle-income countries. Vol. 14, Reproductive Health. Reproductive Health; 2017. p. 1-16.

26. Ali F, Aburshaid H, Ahmad SG, Ashmauey AA. Effect of Planned Health Educational Program on Menstrual Knowledge and Practices among Adolescent Saudi Girls Key phrases. iMedPub Journals. 2017;1-8.

27. Miiro G, Rutakumwa R, Nakiyingi-Miiro J, Nakuya K, Musoke S, Namakula J, et al. Menstrual health and school absenteeism among adolescent girls in Uganda (MENISCUS): A feasibility study. BMC Women's Health. 2018;18(1):1-13.

28. Aflaq F, Jami H. Experiences and Attitudes Related to Menstruation among Female Students. Pakistan J Psychol Res. 2012;27(2):201-24.

29. Parajuli P, Paudel N, Shrestha S. Knowledge and practices regarding menstrual hygiene among adolescent girls of rural Nepal. J Kathmandu Med Coll. 2017;5(1):23-7.

30. Lawal AM, Idemudia ES, Balogun SK. Menstrual attitude dimensions, Anxiety and Body Esteem in adolescent girls. Psychol Heal Med [Internet]. 2019;8pp. Available from: https://doi.org/10.1080/13548506.2019.1640885

31. Lawan UM, Yusuf NW, Musa AB. Menstruation and menstrual hygiene amongst adolescent school girls in Kano, Northwestern Nigeria. Afr J Reprod Health [Internet]. 2010;14(3):201-7. Available from: http://www.ncbi.nlm.nih.gov/pubmed/21495614

32. Fehintola FO, Fehintola AO, Aremu AO, Idowu A, Ogunlaja OA, Ogunlaja IP. Assessment of knowledge, attitude and practice about menstruation and menstrual hygiene among secondary high school girls in Ogbomoso, Oyo State, Nigeria. Int J Reprod Contraception, Obstet Gynecol. 2017;6(5):1726.

33. Aluko OO, Oluya OM, Olaleye OA, Olajuyin A A, Olabintan TF, Oloruntoba-Oju OI. Knowledge and menstrual hygiene practices among adolescents in senior secondary schools in Ile Ife, south-western Nigeria. J Water, Sanit Hyg Dev [Internet]. 2014;4(2):248. Available from: http://www.scopus.com/inward/record.url?eid=2-s2.0-84904717486\&partnerlD=tZOtx3y1

34. Adinma ED, Adinma JI. Perceptions and practices on menstruation amongst Nigerian secondary school girls. Afr J Reprod Health. 2008;12(1):74-83.

35. Suhasini K, Chandra M. Factors Influencing Menstrual Hygiene Practice Among Late Adolescent Girls in an Urban Area of Belgaum. 2016;4(3).

36. Omidvar S, Begum K. Factors influencing hygienic practices during menses among girls from south India-A cross-sectional study. Int J Collab Res Intern Med Public Heal Int J Collab Res Intern Med Public Heal Int J Collab Res Intern Med Public Heal [Internet]. 2010;2(12):411-23. Available from: http://www.iomcworld.com/ijcrimph/

37. Jena P, Andalib S, Khuntia S, Mishra A. Spectrum of menstrual disorder and health consciousness of adolescent school-going girls: A comparative study between the extremes of two socio-economic group. 2017;4(3):235-9.

38. Marván ML, Molina-Abolnik M. Mexican Adolescents' Experience of Menarche and Attitudes Toward Menstruation: Role of Communication Between Mothers and Daughters. J Pediatr Adolesc Gynecol. 2012;25(6):358-63.

39. Communities B. Research and Learning Brief Improving School Attendance and Positive Feelings about Menstruation for Girls in Ghana through a Holistic Menstrual Health and Hygiene Management Approach Key Findings [Internet]. 2020 [cited 2020 May 21]. Available from: https://www.unicef.org/wash/fi

40. Sommer M. Structural factors influencing menstruating school girls' health and well-being in Tanzania. Compare. 2013 May;43(3):323-45.

41. Sharma N. Assessment of knowledge and practice regarding menstrual hygiene among school-going adolescent girls of Jaipur city. J Med Sci Clin Res. 2019;7(7):2808-15.

42. Ghiasi A, Keramat A, Mollaahmadi L. The relationship between attitudes toward menstruation and perimenstrual symptoms among female students of shahroud university of medical sciences, northeast Iran. Shiraz E Med J. 2018 Aug 1;19(8).

43. Owonikoko K, Okunlola M, Ogunbode O, Enabor O, Oluwasola T, Arowojolu A. Menstrual Health of In-School Adolescents in Ibadan: Knowledge, Attitudes and Consequences. Niger Med Pract. 2011;55(5):80-3. 
44. Wong LP. Attitudes toward menstruation, menstrual-related symptoms, and premenstrual syndrome among adolescent girls: A rural school-based survey. Women Heal. 2011;51(4):340-64.

45. Hennegan J, Nansubuga A, Smith C, Redshaw M, Akullo A, Schwab KJ. Measuring menstrual hygiene experience: Development and validation of the Menstrual Practice Needs Scale (MPNS-36) in Soroti, Uganda. BMJ Open [Internet]. 2020 [cited 2020 May 21];10(2):34461. Available from: http://bmjopen.bmj.com/

46. Davis J, Macintyre A, Odagiri M, Suriastini W, Cordova A, Huggett C, et al. Menstrual hygiene management and school absenteeism among adolescent students in Indonesia: evidence from a cross-sectional school-based survey. Trop Med Int Heal [Internet]. 2018 [cited 2019 Jun 21];23(12):1350-63. Available from: https://onlinelibrary.wiley.com/doi/pdf/10.1111/tmi.13159

47. Hennegan J, Dolan C, Wu M, Scott L, Montgomery P. Measuring the prevalence and impact of poor menstrual hygiene management: A quantitative survey of schoolgirls in rural Uganda. BMJ Open. 2016;6(12).

48. McPherson ME, Korfine L. Menstruation across time: Menarche, menstrual attitudes, experiences, and behaviors. Women's Heal Issues. 2004;14(6):193-200.

49. Dolan C, Montgomery P, Scott L, Hennegan J, Wu M, Steinfield L. Keeping African Girls in School with Better Sanitary Care [Internet]. 2018 [cited 2019 Apr 18]. Available from: www.theimpactinitiative.net

50. Padmanabhanunni A, Fennie T. The menstruation experience: attitude dimensions among South African students. J Psychol Africa. 2017;27(1):54-60.

51. Eswi A, Helal H, Elarousy W. Menstrual attitude and knowledge among Egyptian female adolescents. J Am Sci [Internet]. 2012 [cited 2020 May 21];8(6):555-65. Available from:

http://www.americanscience.orghttp//www.americanscience.orgeditor@americanscience.org555http://www.americanscience.org.71

52. Kansiime C, Hytti L, Nalugya R, Nakuya K, Namirembe P, Nakalema S, et al. Menstrual health intervention and school attendance in Uganda (MENISCUS-2): a pilot intervention study. BMJ Open [Internet]. 2020 [cited 2020 Feb 11];10:31182. Available from: http://bmjopen.bmj.com/

53. McMahon SA, Winch PJ, Caruso BA, Ogutu EA, Ochari IA, Rheingans RD. 'The girl with her period is the one to hang her head' Reflections on menstrual management among schoolgirls in rural Kenya. BMC Int Health Hum Rights. 2011;11(1):7.

54. Ramaiya A, Malhotra A, Cronin C, Stevens S, Kostizak K, Sharma A, et al. How does a Social and Behavioral Change Communication Intervention Predict Menstrual Health and Hygiene Management: A Cross-Sectional Study. BMC Public Health. 2019 Aug 2;19(1):112.

55. Kapoor G, Kumar D. Menstrual hygiene: knowledge and practice among adolescent school girls in rural settings. Int J Reprod Contraception, Obstet Gynecol. 2017;

56. Özdemir FNS. Evaluation of Menstrual Attitude of Collegiate Athletes. Life Sci J. 2013;10(6s):295-300.

57. Chinyama J, Chipungu J, Rudd C, Mwale M, Verstraete L, Sikamo C, et al. Menstrual hygiene management in rural schools of Zambia: A descriptive study of knowledge, experiences and challenges faced by schoolgirls. BMC Public Health [Internet]. 2019 [cited 2019 Feb 4];19(1). Available from: https://doi.org/10.1186/s12889-018-6360-2

58. Sivakami M, Laserson KF, Bauman A, Phillips-Howard PA, Thakkar MB, van Eijk AM, et al. Menstrual hygiene management among adolescent girls in India: a systematic review and meta-analysis. BMJ Open. 2016;6(3):e010290.

59. Adinma, E. D., \& Adinma JI. Perceptions and practices on menstruation amongst Nigerian secondary school girls. Afr J Reprod Health. 2008;

60. Yadav RN, Joshi S, Poudel R, Pandeya P. Knowledge, Attitude, and Practice on Menstrual Hygiene Management among School Adolescents. J Nepal Health Res Counc [Internet]. 2018 Jan 1 [cited 2019 Apr 18];15(3):212-6. Available from: http://www.ncbi.nlm.nih.gov/pubmed/29353891

61. Padmanabhanunni, A. Fennie T. The menstruation experience: Attitude dimensions among South African students. J Psychol Africa. 2017;1:54-60.

62. Ten V. Menstrual hygiene: A neglected condition for the achievement of several millennium development goals. Eur Comm Aid. 2007;

63. Aniebue U, Aniebue P, Nwankwo T. "The impact of pre- menarcheal training on menstrual practices and hygiene of Nigerian schoolgirls". Pan Afr Med J. 2010; vol 2(no 9).

64. Massa K, Kilamile F, Safari E, Seleman A, Mwakitalima A, Balengayabo JG, et al. Contributing to the debate on categorising shared sanitation facilities as ' unimproved ': An account based on field researchers ' observations and householders ' opinions in three regions, Tanzania. PLoS One. 2017;12(11):e0185875. 
Tables

Table 1: Socio-demographic characteristics of respondents

\begin{tabular}{|c|c|c|c|c|c|c|c|c|}
\hline \multirow{2}{*}{$\begin{array}{l}\text { Description of variables } \\
\text { Variables }\end{array}$} & \multirow[b]{2}{*}{ Category } & \multicolumn{2}{|c|}{$\begin{array}{l}\text { Public } \\
\text { school }\end{array}$} & \multicolumn{2}{|c|}{$\begin{array}{l}\text { Private } \\
\text { school }\end{array}$} & \multicolumn{2}{|c|}{ Total } & \multirow[t]{2}{*}{ Test statistic } \\
\hline & & $\mathrm{n}$ & $\%$ & $\mathbf{n}$ & $\%$ & $\mathrm{n}$ & $\%$ & \\
\hline \multirow[t]{3}{*}{ Age (years) } & $9-11$ & 22 & 12.4 & 41 & 22.8 & 63 & 17.6 & \multirow{3}{*}{$\begin{array}{l}x^{2}=51.154 \\
d f=2 \\
p=0.0001\end{array}$} \\
\hline & $12-15$ & 103 & 58.9 & 135 & 75.0 & 238 & 66.7 & \\
\hline & $16-19$ & 52 & 29.4 & 4 & 2.2 & 56 & 15.7 & \\
\hline \multirow[t]{2}{*}{ Respondents' class } & Junior secondary & 86 & 48.6 & 16 & 8.9 & 102 & 28.7 & \multirow{2}{*}{$\begin{array}{l}x^{2}=68.440 \\
d f=1 \\
p=0.0001\end{array}$} \\
\hline & senior secondary & 91 & 51.4 & 163 & 91.1 & 254 & 71.3 & \\
\hline \multirow[t]{3}{*}{ Ethnicity } & Yoruba & 150 & 84.7 & 168 & 93.3 & 318 & 89.1 & \multirow{3}{*}{$\begin{array}{l}x^{2}=7.841 * \\
d f=2 ; \\
p=0.020\end{array}$} \\
\hline & Igbo & 16 & 9.0 & 9 & 5.0 & 25 & 7.0 & \\
\hline & $\begin{array}{l}\text { Others (Hausa, Fulani, } \\
\text { Igbira) }\end{array}$ & 11 & 6.2 & 3 & 1.7 & 14 & 3.9 & \\
\hline \multirow[t]{3}{*}{ Religion } & Christianity & 153 & 86.4 & 167 & 92.8 & 320 & 89.6 & \multirow{3}{*}{$\begin{array}{l}x^{2}=4.788 * \\
d f=2 \\
p=0.091\end{array}$} \\
\hline & Islamic & 23 & 13.0 & 13 & 7.2 & 36 & 10.1 & \\
\hline & Atheist & 1 & 0.6 & 0 & 0.0 & 1 & 0.3 & \\
\hline \multirow[t]{4}{*}{ Adolescent resident with } & Father \& mother & 91 & 51.4 & 158 & 87.8 & 249 & 69.7 & \multirow{4}{*}{$\begin{array}{l}\chi^{2}=59.003^{*} \\
d f=3 \\
p=0.0001\end{array}$} \\
\hline & Mother alone & 38 & 21.5 & 10 & 5.6 & 48 & 13.4 & \\
\hline & Father alone & 11 & 6.2 & 2 & 1.1 & 13 & 3.6 & \\
\hline & Guardian & 37 & 20.9 & 10 & 5.6 & 47 & 13.2 & \\
\hline \multirow{4}{*}{$\begin{array}{l}\text { Highest educational status of primary } \\
\text { caregiver }\end{array}$} & No formal education & 21 & 11.9 & 6 & 3.3 & 27 & 7.6 & \multirow{4}{*}{$\begin{array}{l}\chi^{2}=61.536 ; d f=3 \\
p=0.0001\end{array}$} \\
\hline & Primary & 13 & 7.3 & 5 & 2.8 & 18 & 5.0 & \\
\hline & Secondary & 93 & 52.5 & 44 & 24.4 & 137 & 38.4 & \\
\hline & tertiary education & 50 & 28.2 & 125 & 69.4 & 175 & 49.0 & \\
\hline \multirow[t]{3}{*}{ Wealth categories } & Poor & 82 & 46.3 & 37 & 20.6 & 119 & 33.3 & \multirow{3}{*}{$\begin{array}{l}\chi^{2}=29.515 ; d f=2 ; \\
p=0.0001\end{array}$} \\
\hline & Average & 41 & 23.2 & 78 & 43.3 & 119 & 33.3 & \\
\hline & Rich & 54 & 30.5 & 65 & 36.1 & 119 & 33.3 & \\
\hline
\end{tabular}

* = Fishers likelihood ratio

Table 2: The composite measurement of menstrual attitudes dimensions among in-school adolescents 


\begin{tabular}{|c|c|c|c|c|c|c|c|c|c|c|}
\hline \multicolumn{2}{|c|}{ Dimensions of menstrual attitude } & \multicolumn{2}{|c|}{$\begin{array}{l}\text { Public } \\
\text { school }\end{array}$} & \multicolumn{2}{|c|}{$\begin{array}{l}\text { Private } \\
\text { school }\end{array}$} & \multicolumn{2}{|c|}{ Total } & \multirow[t]{2}{*}{$\chi^{2}$ statistic } & \multirow[t]{2}{*}{$\begin{array}{l}\text { Odd } \\
\text { Ratio }\end{array}$} & \multirow[t]{2}{*}{$\begin{array}{l}95 \% \text { Confidence } \\
\text { Interval }\end{array}$} \\
\hline $\begin{array}{l}\text { Menstrual Attitude } \\
\text { blocks }\end{array}$ & $\begin{array}{l}\text { Rating } \\
\text { category }\end{array}$ & $\mathbf{n}$ & $\%$ & $\mathbf{n}$ & $\%$ & $\mathbf{n}$ & $\%$ & & & \\
\hline \multirow[t]{2}{*}{ Positive feelings } & Strong & 64 & 36.2 & 55 & 30.6 & 119 & 33.3 & \multirow{2}{*}{$\begin{array}{l}\chi^{2}=1.261 ; d f=1 \\
p=0.262\end{array}$} & \multirow[t]{2}{*}{0.8} & \multirow[t]{2}{*}{$0.500-1.208$} \\
\hline & Weak & 113 & 63.8 & 125 & 69.4 & 238 & 66.7 & & & \\
\hline \multirow[t]{2}{*}{ Negative Feelings } & Strong & 36 & 20.3 & 22 & 12.2 & 58 & 16.2 & \multirow{2}{*}{$\begin{array}{l}\chi^{2}=4.321 \\
d f=1 \\
p=0.038^{*}\end{array}$} & \multirow[t]{2}{*}{0.6} & \multirow[t]{2}{*}{$0.306-0.971$} \\
\hline & Weak & 141 & 79.7 & 158 & 87.8 & 299 & 83.8 & & & \\
\hline \multirow{2}{*}{$\begin{array}{l}\text { Menstrual } \\
\text { symptoms }\end{array}$} & Positive & 40 & 22.6 & 54 & 30.0 & 94 & 26.3 & \multirow{2}{*}{$\begin{array}{l}\chi^{2}=2.520 ; d f=1 \\
p=0.112\end{array}$} & \multirow[t]{2}{*}{1.5} & \multirow[t]{2}{*}{$0.913-2.361$} \\
\hline & Negative & 137 & 77.4 & 126 & 70.0 & 283 & 73.7 & & & \\
\hline \multirow[t]{2}{*}{ Openness } & Positive & 13 & 7.3 & 31 & 17.2 & 44 & 12.3 & \multirow{2}{*}{$\begin{array}{l}\chi^{2}=8.058 ; d f=1 \\
p=0.05^{\star}\end{array}$} & \multirow[t]{2}{*}{2.6} & \multirow[t]{2}{*}{$1.324-5.204$} \\
\hline & Negative & 164 & 92.7 & 149 & 82.8 & 313 & 87.7 & & & \\
\hline \multirow{2}{*}{$\begin{array}{l}\text { Acceptance of } \\
\text { menarche }\end{array}$} & Positive & 50 & 28.2 & 64 & 35.6 & 114 & 31.9 & \multirow{2}{*}{$\begin{array}{l}\chi^{2}=2.192 ; d f=1 \\
p=0.139\end{array}$} & \multirow[t]{2}{*}{1.4} & \multirow[t]{2}{*}{$0.896-2.192$} \\
\hline & Negative & 127 & 71.8 & 116 & 64.4 & 243 & 68.1 & & & \\
\hline \multirow{2}{*}{$\begin{array}{l}\text { Living with } \\
\text { menstruation }\end{array}$} & Positive & 68 & 38.4 & 115 & 63.9 & 183 & 51.3 & \multirow{2}{*}{$\begin{array}{l}\chi^{2}=23.174 ; d f=1 ; \\
p=0.0001^{*}\end{array}$} & \multirow[t]{2}{*}{2.8} & \multirow[t]{2}{*}{$1.846-4.356$} \\
\hline & Negative & 109 & 61.6 & 65 & 36.1 & 174 & 48.7 & & & \\
\hline
\end{tabular}

* = significant association.

Table 3: Multivariate regression of variables influencing menstrual hygiene attitude of in-school adolescent girls 


\begin{tabular}{|c|c|c|c|c|}
\hline Factor & Category & Odd Ratio (OR) & 95\% Confidence Interval (Cl) & p-value \\
\hline \multirow[t]{3}{*}{ Age (years) } & 9-11- early adolescence & 0.764 & $0.218-2.678$ & 0.674 \\
\hline & 12-15- middle adolescence & 1.122 & $0.413-3.048$ & 0.821 \\
\hline & 16-19- late adolescence & Ref. & . & . \\
\hline \multirow[t]{2}{*}{ Class } & Junior Secondary & 2.583 & $0.916-7.281$ & 0.073 \\
\hline & Senior secondary & Ref. & . & . \\
\hline \multirow[t]{3}{*}{ Ethnicity } & Yoruba & 5.694 & $1.308-24.794$ & 0.020 \\
\hline & Igbo & 14.204 & $1.266-159.414$ & 0.031 \\
\hline & Others (Hausa, Fulani, Igbira) & Ref. & . & . \\
\hline \multirow[t]{3}{*}{ Religion } & Islamic & 0.528 & $0.140-1.985$ & 0.345 \\
\hline & Christianity & 0.405 & $0.405-0.405$ & . \\
\hline & Others (traditional, none) & Ref. & . & . \\
\hline \multirow[t]{4}{*}{ Residence with.. } & Both parents & 0.932 & $0.297-2.932$ & 0.905 \\
\hline & Mother & 0.666 & $0.163-2.726$ & 0.572 \\
\hline & Father & 347598.004 & $0.000^{-a}$ & 0.980 \\
\hline & Others (grandparents, relatives) & Ref. & . & . \\
\hline \multirow[t]{4}{*}{ Caregiver's highest level of education } & No formal education & 2.687 & $0.562-12.843$ & 0.216 \\
\hline & Completed primary & 1.189 & $0.232-6.090$ & 0.835 \\
\hline & Completed secondary & 2.467 & $1.047-5.814$ & 0.039 \\
\hline & Tertiary & Ref & . & . \\
\hline \multirow[t]{3}{*}{ Wealth } & Poor & 0.777 & $0.335-1.804$ & 0.557 \\
\hline & Average & 1.080 & $0.476-2.447$ & 0.854 \\
\hline & Rich & Ref & . & . \\
\hline
\end{tabular}

$\mathrm{a}=$ Floating point overflow occurred while computing this statistic. Its value is therefore set to system missing.

\section{Figures}




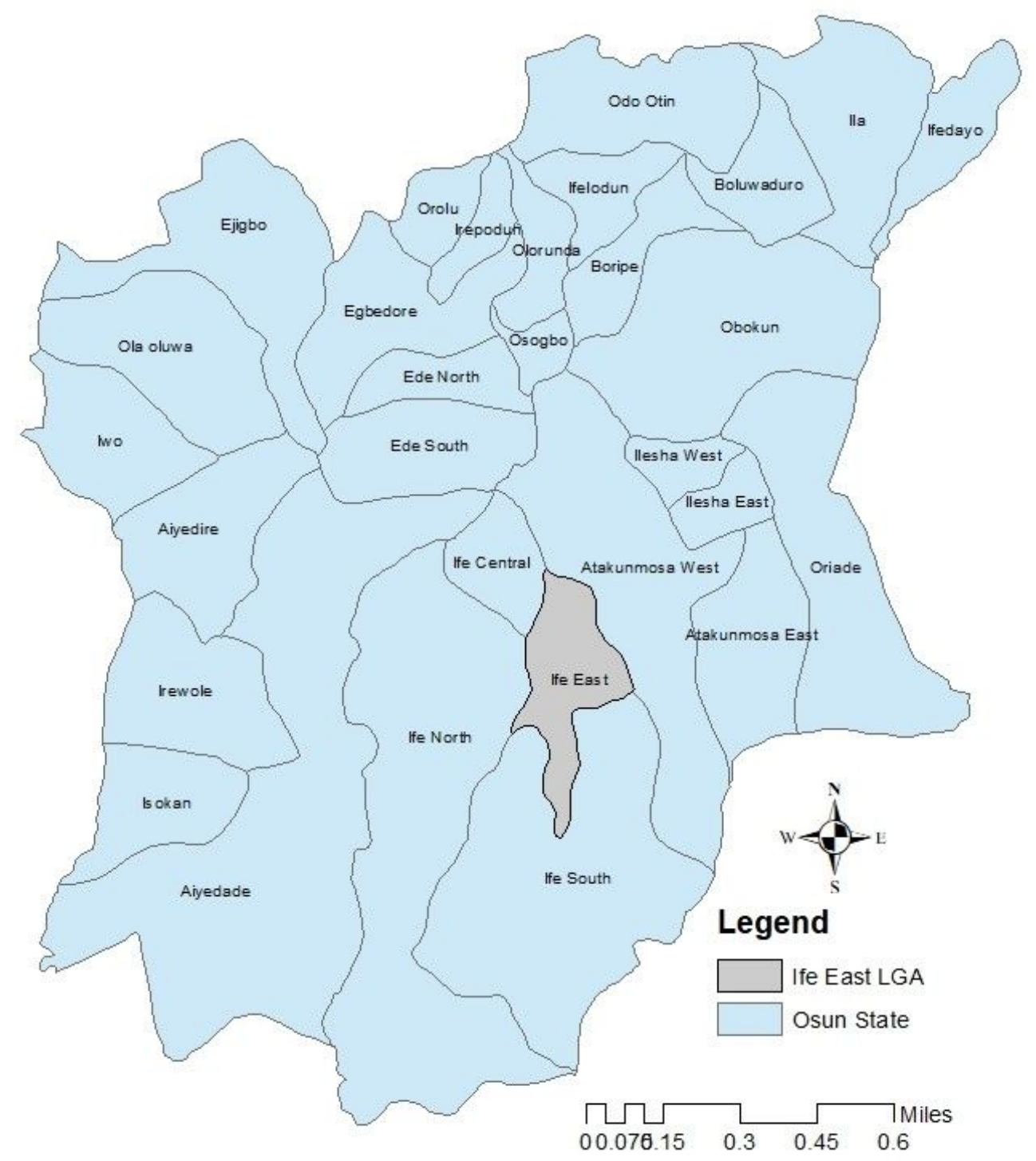

Figure 1

MAP

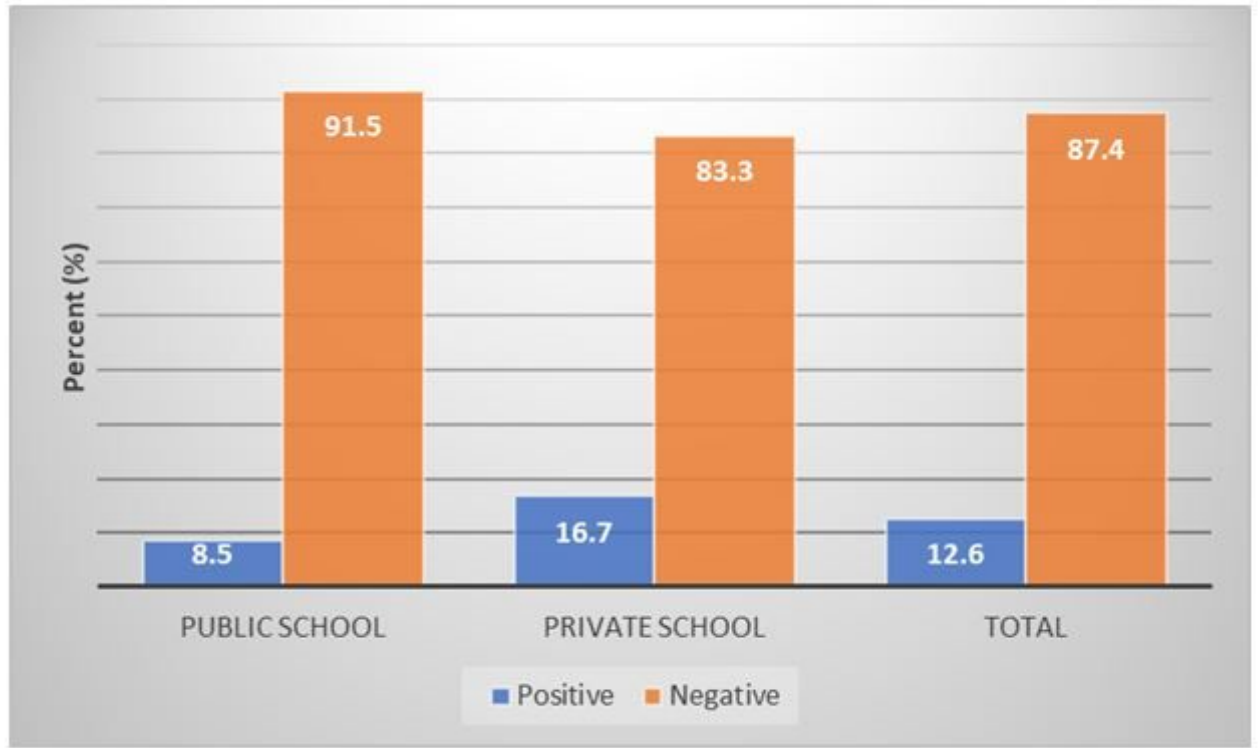

$\chi^{2}=5.437 ; \mathrm{df}=1$;

$\mathrm{p}=0.020^{*}$,

$\mathrm{OR}=2.2$,

$95 \% \mathrm{CI}=1.118-4.172$ 


\section{Figure 2}

Composite attitude on menstruation among in-school adolescents

\section{Supplementary Files}

This is a list of supplementary files associated with this preprint. Click to download.

- SupplementaryfileMAQMHMQuestionnaire.docx

- completedSTROBEcrosssectionalchecklist.docx 